\title{
'RITUALS OF RESISTANCE, WEAPONS OF THE WEAK': TOWARD AN AFRICAN PENTECOSTAL TRANSFORMATIVE HOLY COMMUNION MISSIOLOGY ${ }^{1}$
}

\section{J Kaunda}

\section{University of South Africa}

\begin{abstract}
:
The article defines symbolic inversion as transgressive behaviour which most traditional Zambian societies reenacted in the ritual context as a dynamic cultural form. It argues for critical reclamation and reconstitution of symbolic resistance dimension of Ndembu ritual (people of North-west Zambia) to construct transformative Holy Communion missiology within Pentecostal Assemblies of God in Zambia (PAOG-Z). The symbolic resistance of Ndembu ritual seems to have potential to give fresh perspective on how Holy Communion could function as mundus inversus (world-upside-down) - a way of resisting negative prevailing social order. Finally some contours for Holy Communion Missiology are suggested on methodological and practical level to help the community of faith refocus its Holy Communion performances to resisting anti-life and death-dealing forces.
\end{abstract}

Keywords: PAOGZ, Holy Communion Missiology, Symbolic Inversion, weapons of the weak

\footnotetext{
${ }^{1}$ This article draws on the interviews for the Book Project funded by John Templeton Foundation, administered by the Nagel Institute of Calvin College under the theme "Christianity Theology: African Realities and African Hope."
} 
'Rituals of resistance, weapons of the weak': Toward an African Pentecostal transformative Holy Communion Missilogy.

\section{INTRODUCTION}

The Holy Communion (the Lord's Supper) ${ }^{2}$ is foundational to the faith of the Pentecostal Assemblies of God in Zambia (hereafter PAOG-Z) community and is one of the only two ordinances ${ }^{3}$ recognised. The ritual is understood as a symbolic remembrance of the suffering and death of Jesus Christ for humanity's salvation (The Constitution and ByLaws of PAOG-Z- hereafter the Constitution). In most PAOG-Z churches, the Holy Communion is often observed the first Sunday of every month. It consists of the elements of bread and the grape juice ${ }^{4}$ as re-enactment of Christ's suffering and death as symbol expressing the mission of God as "God's interruptions in daily experiences of human beings. It is symbolic participation in all that Christ intends to achieve in the world. The participation in the Holy Communion is missiological confrontation with veritable incubus of existential experiences of humanity. The Holy Communion brings the community of faith into missional agreement with God's activities in and for the world.

It is a ritual "enjoined in the Scripture" through which believers re-enact human injustice and violence which found decisive injurious and despicability in the death of Christ on the cross (The Constitution n.d: 40). The Holy Communion is understood as "encapsulating Christ's incarnation, life, death and resurrection through which he challenged violence and social injustice" (Nyirenda). Thus, the Holy Communion as

\footnotetext{
2The Holy Communion and the Lord's Table are the two specific terms used in describing the Eucharist in the Constitution and By-laws of PAOGZ. It is also known as the Lord's Supper, or the Last Supper depending on the tradition.

${ }^{3}$ The other ordinance is water baptism by immersion.

4 The juice is never referred to as wine but fruit of the vine, or just juice.
} 
an eschatological event could be considered as mundus inversus (symbolic inversion). It was a messianic missiological resistance to prevailing social order in respect to realities of injustice, oppression, poverty, discrimination, inequality and violence.

Thus the aim is to engage PAOG-Z notion of Holy Communion through anthropological theory of the rituals of resistance which is used to demonstrate the missional nature of the Holy Communion. The argument of this article is that symbolic inversion as a theoretical tool to engage the Holy Communion has potential to transform the way the ritual is done and understood by recasting it to serve as a form of socio-political and economic criticism that could call attention to the struggles of those on the margins.

\section{RITUALS OF RESISTANCE: MUNDUS INVERSUS IM- AGINATION}

The Ndembu people, whose ritual thinking is used as point of departure in this article, occupy western portion of Mwinilunga District in North-western Province of Zambia. I am aware that symbolic inversion is a widespread cultural phenomenon in most cultures around the world. The Ndembu rituals are deeply entrenched in symbolic inversion. But for the sake of this paper, I refer to Ndembu symbolic actions, a way of thinking that tends to reverse normative values of society. In the Reversible world, Barbara Babcock (1978:14) offers the following characterization of this topos as "any act of expressive behavior which inverts, contradicts, abrogates, or in some fashion presents an alternative to common held cultural codes, values, and norms be they linguistic, literary or artistic, religious or social and political." The early anthropologists who researched in Africa such as Max Gluckman (1954), characterised such ritual actions as 'rituals of rebel- 
'Rituals of resistance, weapons of the weak': Toward an African Pentecostal transformative Holy Communion Missilogy.

lion' (termed here as rituals of resistance). ${ }^{5}$ As to the fact that there are such rituals of resistance in most African ritual performances, Ndembu to be more precise, anthropologists ${ }^{6}$ are in agreement and have given ethnographic examples of contrary or non-normative behaviours in certain ritual contexts. Ethnographic contentions arise typically over the question of how such rituals of resistance impact or contribute to the transformation of the nature of structured societies more broadly. The fact is that there can be no ritual performance among Ndembu people without engaging in such oppositional behaviours however that might be interpreted by ethnographers.

Ndembu rituals are deeply entrenched with oppositional behaviours include lewd conduct, gender swaps or adopting genderless behaviour, same-sex intercourse, social status reversals, and various other forms of symbolic resistance to normative social influence (Kaunda 2015). Jacob Pandian (2001) rightly argues that it is possible to identify such contrary non-normative behaviours collectively as anti-structure mundus inversus, thereby contrast them with the normative cognitive or social structure of society.

In his book, Revelation and Divination in Ndembu Ritual, Victor Turner (1975:31) who did numerous publications on Ndembu ritual, wrote that he began his research among

\footnotetext{
${ }^{5}$ Gluckman was one of the earliest anthropologists who research among the Zulu people of KwaZulu-Natal in South Africa and some ethnic groups in Zambia. He presented his finds as the Frazer lecture at the University of Glasgow in 1952 under the title, Rituals of Rebellion in South-East Africa.

${ }^{6}$ Some anthropologists have criticised Gluckman for failing to give specific ethnographical accounts on the African attitudes toward symbolic inversion. For various criticisms and validations see Hilda Kuper (1961);Edward Norbeck (1963); Victor Turner (1969); Susanne Schröter (2004); Jane T Creider and Chet A. Creider (1997) and Todd Sanders (2000:469)
} 
them "as an agnostic and monistic Materialist." And later acknowledged;

I learned from the Ndembu that ritual and its symbolism are not merely epiphenomena or disguises of deeper social and psychological processes, but have ontological value, in some way related to man's (sic) condition as an evolving species, whose evolution takes place principally through its cultural innovations.

In Ndembu society, socio-cultural landscapes are created, recreated and transformed and retransformed by human symbolic actions of the community through rituals. The people perform these rituals as social mechanism for resisting and reaffirming their humanity and develop new ways of being and becoming a more just community so that social healing can follow in the community. In reference to Ndembu cosmology, Catherine Bell (1997:40) argues, rituals do not merely restore social equilibrium, rather are "part of the ongoing process by which the community was continually redefining and renewing itself."

Turner (1964:30-31) writes that any symbol in ritual involves a dynamic exchange between their two poles that is the sensory and ideological. The sensory or normative pole concentrates on the very literal physiognomies of the symbol as a way to provoke desire and feelings. The second is the ideological pole which challenges status quo and seeks to rearrange social norms and cultural values of people. According to Turner (1969:108), ideologically, Ndembu symbolic actions in the ritual have been utilized as "the power of the weak" that enabled the weak to break free from cultural bounds of society as long as they remained within the spaces of the ritual. This does not mean that the symbolic inversion had an immediate impact on the general society broadly after the ritual but points to the fact that traditional people 
'Rituals of resistance, weapons of the weak': Toward an African Pentecostal transformative Holy Communion Missilogy.

have instruments to critique, subvert and resist dominant social order.

The subversive nature of rituals in some African societies made Gluckman to classify them as "rituals of rebellion". They are rituals of rebellion as they demand resistance to life denying socio-cultural, economic and political arrangement through enactment of the possible just social order. As Bell (1997:41) observes, the sensory pole is an inversion of the sensual experiences associated with a particular symbol which are expected to shape the resultant associated ideological values into people's consciousness, "endowing the ideological with sensory power and the sensory with moral power." Therefore, the ritual is more than just presenting the social realities by a symbol but a more subtle means for engaging in the process of transformation of social order and reordering of power relations. That is why there are various rituals entrenched with a specific symbolic inversion. For instance, they are those in which people went on a kind of hunger strike, those in which the king/leaders are reduced to servants especially before coronation, in some people behaved like certain animals, others are based on gender reversals and many other rituals of symbolic resistances have been reported by various anthropologists across the continent (Kuper 1961; Norbeck 1963; Turner 1969; Schröter 2004; Creider and Creider 1997; Sanders 2000). This suggests that the ritual can never be an end in itself it always points to the way people must live out their lives once emerge out of the liminalities of the ritual. It points to what must be changed in the ordering of life and society. It is in a kind of a context that Jesus instituted the Holy Communion as a resistance to the injustices that he struggled against such as gender inequality, poverty, disease, ideological enslavement, violence and all forms of marginalisation, dis- 
crimination and injustice. As explained below, Holy Communion was ritualization of human resistance against antilife forces.

\section{THE HOLY COMMUNION MISSIO DEI AS MUNDUS IN- VERSUS}

In order to demonstrated the missiological implications of the Holy Communion as mundus inversus, I draw on the interviews I conducted in Zambia in the first half of 2016 for the research project funded by the John Templeton Foundation, administered by the Nagel Institute of Calvin College under the theme "Christianity Theology: African Realities and African Hope." I wanted to find out how PAOG-Z ministers understand the Holy Communion both in relation to the mission of God and in Zambian society in particular. What became clear during this research was the extraordinary missiological imagination with which some pastors conceptualise the Holy Communion. This was born out of the interviews I conducted with five pastors in PAOG-Z in different churches in various cities in Zambia. For example, Clement Kunda of PAOG-Z in Ndola describes Holy Communion in missiological terms:

The Holy communion, it had a symbol beyond just his [Jesus] death but also as a ritual of engaging with social issues of his context at that time, because the people he ministered to, many of them had no bread ... the people in need of food in Palestine had no food there were peasants ... Holy Communion had more than just a symbol of his death but a symbol of challenging the status quo of his society those who had no food, so that is why people ate as a resistance of those or to the powers of that time who had neglected the masses and they had acquired wealth for themselves. 
'Rituals of resistance, weapons of the weak': Toward an African Pentecostal transformative Holy Communion Missilogy.

In Christians and Roman Rule in the New Testament, Richard J. Cassidy (2001) describes the political and economic conditions of Augustus' rule in more detail. He writes that Roman elite enjoyed great wealth from the purse of conquered colonies and the trade that increased as the borders moved outward. The largest population of 95 percent of Roman Empire at the time of Jesus was peasant and lived in abject poverty. They were impoverished to the bone. G.E.M.D.S. Croix (1981:14) in The Class Struggle in the Ancient Greek World argues that the peasantry community in the Roman Empire was "thoroughly and effectively exploited than most other societies which rely largely upon peasant population for their food supplied." In agreement with Croix, Amos Yong (2010:44), in his book, In the Days of Caesar, details how the peasant provided cheap labour and produce goods for elite consumption besides paying all kinds of taxes on produce, sales taxes, temple taxes, occupational taxes, custom taxes, transit taxes, and many others. Raymond Nyirenda of the Northmead Assembly of God in Lusaka argues that,

The ordinance of Holy Communion in my view ushers in a new order and if you look at the life of Christ, he was ushering a new order. That did not settle well with the then status quo because even the way Christ expected people to relate to one another in this new order is very different ... from what was obtaining then. That is why you find that when the Apostles broke bread which was kind of communion was a follow up from this institution. They did not only break bread but they shared what they had in common, they reached out to each other's needs and so forth. So it was really ushering in a new order where people in this order because he gave us his body, his body was broken for each one of us that we might be whole, that we must receive the newness of life. Newness of life based on kingdom values, based on his teaching and values which was to reach out to one an- 
other, care for one another which was not to look out to our own interests.

This argument seems to be suggested that participation in the Holy Communion signifies belonging to 'a new order.' The church as an agent of 'a new order' is sustained by its practice of the Holy Communion. Yet this practice is not for the church itself but for sake of the whole world - participation in the Holy Communion has implications for participation in the mission of God. This means that the ritual has significance only as God's means for engaging the whole world. Nyirenda brings a contextual dimension to the church's participation in the Holy Communion. He stresses, "it has social implications in as far as the social order is concerned because this new life has to be lived out in our context and if we are going to live out in a context where there is lack, brokenness and so forth. So this new life must affect positively our social context." Aaron Ngwira, Bishop in PAOG-Z and senior pastor at Evangel Assembly of God in Chingola agrees, "I believe so, it does. Knowing what it represents and practising it as an ordinance, makes one to lead a subjective social engagement." Similarly Kunda explains, "Emblems, visual, carries more message which has implications for social engagement than Just words. It reminds believers about the everlasting love of God - God sent his Son to die for the world - this suggests the mission of God."

Even more forcefully is the argument coming from Nyirenda:

This is because of the new life we have received in Christ that expects no less than engaging holistically. In fact in my view then Holy Communion should not only remind us of the new life only but the unity we have in Christ because this new dispensation that has been ushered by the new covenant reminds us that we are one in Christ. There is neither Greek nor Jew, [neither] Gentile nor Greek. It also reminds us of coming against issues of so- 
'Rituals of resistance, weapons of the weak': Toward an African Pentecostal transformative Holy Communion Missilogy.

cial injustice because in the day of Jesus Christ there were divisions, there were issues of favouritism, segregation, marginalisation, gender injustice, poverty, poor leadership, putting one race above the other and so forth. But in this new dispensation this is to be discarded.

Nyirenda further argues:

What is wrong about gender injustice, tribalism, racism and nepotism and discrimination is when we now start marginalising or start considering other people inferior or start disadvantaging other people then we have departed from the norms of Christ from the teachings or dictates of this new life or from the dictates of this new unity. Because what is condemned is when you start this segregation, this marginalisation, this disadvantaging of people that is what is condemned but working on the footing, relating on the same footing there been equity, there been equality of all ... no one comes in before the other then we are living in keeping with the teachings of Jesus Christ, we are living in keeping with the norms of this new life. So we should affect society to the extent that they realise that ... Christ preaches that there is no one who is more human than the other, there is no [one] that is superior [to] the other... So really, Holy Communion talks of this new dispensation, ushers in a new order that requires us to live as one, that requires us to live selfless lives, to consider others, to minister to others, and to reach out to the needs of others, to really care for one another and the world.

The interesting aspect of the above statements is that Holy Communion is understood as not only a ritual that unites the Christian community but the very act of practicing it is itself an engagement in the mission of God. In his The Symbolic Imagination, Robert Barth (2001) argues that the Holy Communion is encrypted in a symbol language - a primary language through which human beings have always made sense of the mysteries of God. The ritual, as Kunda also 
explains that the Holy Communion reveals that which can be known about "the mystery of God and divine mission on earth". Kunda further notes, "The Holy Communion takes a ritual form, this is well known in African culture, as this is believed to open an access to God who in turn endows the ritual with its sacredness". This means that the ritual makes sense to be understood as a ritual of resistance in keeping with African worldview, Ndembu in particular.

\section{RECLAIMING TRANSFORMATIVE HOLY COMMUNION MISSIOLOGY}

The very existence of the church as 'a new order' in the world is meant to be a divine symbolic resistance to injustice and evil in the world. The church resists evil in the world by enabling its member to live contrary to prevailing social order permeated by injustice, inequality, consumerism, violence, discrimination, racism, ethnocentrism, corruption and all evils that define it.

The argument here is that the Holy Communion, then, is a set of symbols that Jesus chose to use as symbolic inversion of everything that has gone wrong in the world. It is God's missional vehicle for engaging the world. The church, through its regular re-enactment of the Holy Communion functions as both a concrete expression of "God's yes" to the world which is also "God's no" to injustice and violence in the world. In the institution of the Holy Communion Jesus chose two symbols which were common in Palestine in the first century, namely, 'bread' and 'wine' (Luke 22:14-20). There are lessons that can be gleaned from the context of the Holy Communion: 
'Rituals of resistance, weapons of the weak': Toward an African Pentecostal transformative Holy Communion Missilogy.

First, these symbols therefore, point to pervasiveness of sin in human life and society which is the root of all evil. ${ }^{7}$ Ngwira explains,

The emblems of bread and wine represent the broken body of Christ which is a symbol of broken world, starvation, hunger or suffering. The blood he shed on Calvary for the remission of sin...also can represent thirsty and lack in the world.

Kunda stresses, "ultimately these symbols point to more than just violent and unjust death of Jesus but to the realities of human struggles during Jesus' time." "If the Holy Communion has to do with the new covenant as understood in Assemblies", Nyirenda argues, then that indicates "a new community - formation of a new order different from the one that existed. This can only be possible when the church live differently from the way of the world." These perspectives are similar to R. Alan Streett's (2013) argument. He highlights that the symbols of bread and wine were the most basic need of the majority of people in first century Palestine. Even today, food (bread) and drinking (wine) remain indispensable need in human lives.

The right to good deity is the right to life. Life and food cannot be artificially separated. It is food that sustains life. In Zambia today, every day, most of unemployed men and women; street kids wake up every day searching for food wherever it can be found, mostly in the garbage (Dube 1997). Musa Dube (1997) writes that those who have jobs work hard to ensure that food is available in their homes. Nations around the world are working tirelessly developing and reformulating economic strategies that can guarantee

\footnotetext{
${ }^{7}$ R. Alan Streett (2013) in his interesting work engages with human torture in Latin America from Eucharistic perspective and demonstrates how torture was implicated in Jesus' institution of Eucharist.
} 
food security. That how essential food is in sustaining human life, without which life cannot be sustained.

The same could be said about drinking, especially clean water. The recent discussions on Biblical archaeology have demonstrated how wine is also historically, archaeologically indispensable and there is written evidence for its central place across ancient Mediterranean. In the Roman period, wine was cheap enough for almost everyone to afford (though some of it was of low quality). Archeologists, Randall Heskett and Joel Butler (2012) in their ground-breaking book, Divine Vintage: Following the Wine Trail from Genesis to Modern unearthed that wine was drunk for health and hygienic purposes as most water was polluted. Wine was also added to water as purifying agent. Thus, wine may have functioned as water which is necessary for human survival.

Second, Jesus reclined at the table with the marginal and the poor. Dennis Smith (1987:623) who has done an extensive research on the Greco-Roman tradition of reclining at the table noted that the practice of reclining for the meal was fundamentally a mark of social status and determined boundaries in which one might transverse. He (2012:24) observes that those who reclined at the same table had their ranks relative to one another. The mixing of social classes was forbidden. In fact, Smith $(2012,1987)$ believes that the practice was universal throughout the Greco-Roman world. At the time of Jesus not everyone had the right to recline at the table. Reclining was extended only to the freemen, particularly Roman citizens. Part of the banquet discourse was to remind those who reclined of their social status by the fact that they reclined. Smith (1987:623) notes, in the GrecoRoman tradition of reclining at the table, women, children, foreigners and slaves were to sit when they ate as they had no rights to recline. In contrast, at the Holy Communion, 
'Rituals of resistance, weapons of the weak': Toward an African Pentecostal transformative Holy Communion Missilogy.

people who seemed to have no rights to recline at the table reclined with Jesus. In doing so, Jesus symbolically resisted the reciprocity and status-seeking of Roman and Jewish religious leaders' meals, by reclining on the same table with those who society denied the rights to equality.

Less obviously, Jesus engaged in the mundus inversus not just by his choice of symbolisms of bread and wine but also by his choice of people who reclined with him at the table. He used the already well established elements, essential to human survival, which are at the base of global human struggle (violence and injustice). He used them figuratively as tools for resisting the powerful and the rich in the Roman Empire. He used the Greco-Roman meal etiquette that promoted injustice and inequality to subvert the empire. Thus, the disciples who shared in the Holy Communion were aware of Jesus' subliminal message. This was a simple but clear reminder to the community of faith that God's will is that there should be food and clean water for all but that food is not readily available because of structural injustice (Dube 1997). ${ }^{8}$

The fact that PAOG-Z functions with an open invitation to Holy Communion, means anyone, everyone who believes in Jesus - baptized or not baptized - can choose to partake of the Holy Communion. This demonstrates that all are equal and must have access to life-giving resources that humanises. It means that to eat bread and drink wine in the Holy Communion ritual is to resist against poverty, water pollution which encapsulates all anti-life and death dealing forces wherever they are found. This means that partaking of the

${ }^{8}$ Musa W. Shomanah Dube (1997) discusses the Lord Prayer in the context of globalisation which she sees as grandchild of colonialism and imperialism. She gives a very interest discussion on the priority of food in the Lord's Prayer. 
Holy Communion is not a pleasant thing, for in the ritual, believers are confronted with their own contribution and perpetuation of evil and collective human injustice and violence experienced daily in their communities. It is eating and drinking for resistance against child starvation, gender injustice, for the minority and all those denied human rights, ecological destruction, poor governance, corruption, life-denying public policies and all anti-life forces. This raises some questions: in what ways does participation in the Holy Communion help the Christian community become social conscious? How can we practice the Holy Communion for social transformation? It is not just a ritual of reconciliation for the estranged but also a ritual of radical but silent resistance against anti-life forces in society. ${ }^{9}$

In Africa today, Holy Communion presents the enduring violence and systemic injustice manifesting through massive poverty, terrorism and extremism, migration, ecological crisis, Ebola, HIV and AIDS, gender injustice and inequality, rape, civil wars, religious violence, ethnicity, racism, greediness, xenophobia, corruption, capitalism, consumerism and many other life-destroying forces. Is the church promoting "a new social order" based on justice and equality through its practice of Holy Communion? How can the church deliberately and decisively engage in Holy Communion bearing in mind its symbolic inverse nature? According to the respondents, the Holy Communion has to be done within the context of prevailing social challenges to proclaim the dawn of an alternative or new social order, commonly referred to as the World Turned Upside Down, which Jesus demon-

${ }^{9}$ It is important to also note that in the context of the ritual of the Holy Communion, Jesus also gave a discourse on the kind of leadership he expected to aid people in symbolic resistance (Luke 22). 
'Rituals of resistance, weapons of the weak': Toward an African Pentecostal transformative Holy Communion Missilogy.

strated in symbolisms of the Holy Communion. For during the inauguration of Jesus - Jesus refused to eat bread and drink wine for these are the foundation of human needs and are a result of much injustice and violence in the world. By resisting, he introduces a new community that should look out for the needs of each and thereby become an extension of the incarnation of Christ. The Holy Communion demands alternative living for it reaffirms Jesus alternative community which reenacts the Kingdom of God's principles of justice, peace and righteousness.

Thus, symbolisms of bread and wine are related to God's mission in the world that is transmitted by them and its purpose. This can be termed as Holy Communion from the margins which seeks to counteract injustices in life, church, and society. This is the kind of Holy Communion that can contribute to the formation of transformative spirituality and mission. It can be argued that transformative Holy Communion in the sanctuary only has full integrity when the community of faith choose to re-enact both symbolically and practically specific social challenges in their daily life. It seeks to be an alternative Holy Communion consciousness against the perception that Holy Communion is only about unsocially engaged remembrance based on cerebral, psychological exercise to recollect past events of Jesus thereby it continues monotonous into the limbo of meaningless ritual which are done for the sake of fulfilling certain religious duties. It is participation in Messianic resistance against social death, anti-life forces. This is why the church's neglect of symbolic inverse in the Holy Communion has been so catastrophic, and is closely linked to consumerism, capitalism and other injustice and violence. The call is to reclaim the symbolic inversion of the Holy Communion as it missiological motif. 


\section{CONCLUSION}

It can be concluded that the Holy Communion is a paradigmatic ritual of resistance which has as its paramount concern with bread and wine as instruments for reordering of social relationships for justice and equality. The interviews with PAOG-Z pastors demonstrate that transformative Holy Communion missiology is not only in what we do during the ritual service but more also in how church pragmatically live out the missional message embedded in the Holy Communion. It calls for realisation that bread and wine as human's basic needs are coloured with injustice and violence. Thus, rethinking the Holy Communion in missional terms is needed today more than ever before for sustenance in a time of hunger, contaminated water, conflict for power, nepotism, HIV and AIDS and emancipation from undemocratic democracy and an unjust political economic structure that continues to crush masses underfoot.

\section{Bibliography}

Babcock, Barbara. Introduction to the reversible world: Symbolic inversion in art and society (Itchaca: Cornell University Press, 1978).

Barth, J. Robert. The Symbolic Imagination: Coleridge and the Romantic Tradition, second edition (England: Fordham University Press, 2001).

Bell, Catherine. Ritual: Perspectives and Dimensions (Oxford: Oxford University Press, 1997).

Bosch, J. David. Transforming Mission: Paradigm Shifts in Theology of Mission (Maryknoll: Orbis, 1991).

Cassidy, Richard J. Christians and Roman Rule in the New Testament: New Perspectives: Companions to the New Testament (New York: The Crossroad Publishing, 2001).

Creider, Jane T and Chet A. Creider. "Gender, Inversion in Nandi Ritual," Anthropos, 92, no. 1-3 (1997): 51-58.

Croix, G.E.M.D.S. The Class Struggle in the Ancient Greek World (New York, NY: Cornell University Press, 1981).

Dube, Musa W. Shomanah. "Praying the Lord's Prayer in a Global Economic Era," Ecumenical Review 49 (1997): 439-450.

Gluckman, Max. Rituals of Rebellion in South-East Africa: The Frazer Lecture, 1952 (Manchester: Manchester University Press, 1954). 
'Rituals of resistance, weapons of the weak': Toward an African Pentecostal transformative Holy Communion Missilogy.

Heskett, Randall and Joel Butler. Divine Vintage: Following the Wine Trail from Genesis to Modern Age (New York: Palgrave, 2012).

Kaunda, Chammah J. "Betrayed by Cultural Heritage: Liminality, Ambiguous Sexuality and Ndembu Cultural Change - An African Ecclesia-Ethic of Openness," Alternation Special Edition No 14 (2015): 22 - 44.

Kuper, Hilda. An African aristocracy (London, Oxford University Press, 1961) and Edward Norbeck, "African Rituals of Conflict," American Anthropologist 65 (1963): 1254-1279.

Pandian, Jacob. "Symbolic Inversions: An Interpretation of Contrary Behavior in Ritual," Anthropos, 96, no. 2 (2001): 557-562.

Sanders, Todd. "Rains Gone Bad, Women Gone Mad: Rethinking Gender Rituals of Rebellion and Patriarchy," The Journal of the Royal Anthropological Institute, 6, no.3 (2000): 469-486.

Schröter, Susanne. "Ritual of Rebellion - Rebellion as Ritual: A Theory Reconsidered," in The Dynamics of Changing Rituals: The Transformation of Religious Rituals within their Social and Cultural Context ed. Jens Kreinath, Constance Hartung and Annette Deschner (New York: Peter Lang, 2004), 41-58.

Smith, Dennis E. "Table Fellowship as a Literary Motif in the Gospel of Luke," JBL 106 (1987), 613-628

Smith, Dennis E. "The Greco-Roman Banguet as a Social Institution," in Meals in the Early Christian World Social Formation, Experimentation, and Conflict at the Table edited by Dennis E. Smith and Hal E. Taussig (New York: Palgrave Macmillan, 2012), 23-33 .

Streett, R. Alan. Subversive Meals: An Analysis of the Lord's Supper under Roman Domination during the First Century (Eugen: Wipf and Stock Publishers, 2013).

Turner, Victor. "Process, System, and Symbol: A New Anthropological Synthesis," Daedalus, 106, 3 (1977): 61-80.

Turner, Victor. "Symbols in African ritual," In Symbolic Anthropology: A reader in the study of Symbols and Meanings ed. Dolgin, Janet L. David S. Kemnitzer and David M. Schneider (New York: Columbia University Press, 1977), 183194 ,

Turner, Victor. "Symbols in Ndembu ritual," In Closed systems and open minds: The limits of naivety in social anthropology ed. Max Gluckman (Edinburgh: Oliver and Boyd, 1964), 20-51.

Turner, Victor. "Three Symbols of the Passage in Ndembu Circumcision Ritual: An Interpretation," In Essays on the Ritual of Social Relations ed. Glunckman, Max (Manchester: Manchester University Press, 1962), 122-180.

Turner, Victor. Revelation and Divination in Ndembu Ritual (Cornell University Press, 1975).

Turner, Victor. The Ritual Process: Structure and Anti-structure (Ithaca, N.Y.: Cornell University Press, 1969).

Yong, Amos. In the Days of Caesar: Pentecostalism and Political Theology (Grand Rapids: Eerdmans, 2010). 